OPEN ACCESS

Edited by:

Cornelia E. Nauen,

Mundus Maris, Belgium

Reviewed by:

Karina Ryan,

Western Australian Fisheries and Marine Research Laboratories,

Australia

Jorge M. S. Gonçalves,

University of Algarve, Portugal

*Correspondence:

Harry K. Gorfine

hgorfine@unimelb.edu.au

Specialty section:

This article was submitted to

Marine Fisheries, Aquaculture and Living Resources,

a section of the journal

Frontiers in Marine Science

Received: 11 October 2021

Accepted: 27 December 2021

Published: 17 January 2022

Citation:

Jalali A, Bell JD, Gorfine HK, Conron S and Giri K (2022) Angling to Reach a Destination

to Fish-Exploring the Land and Water Travel Dynamics of Recreational Fishers in Port Phillip

Bay, Australia.

Front. Mar. Sci. 8:793074. doi: 10.3389/fmars.2021.793074

\section{Angling to Reach a Destination to Fish-Exploring the Land and Water Travel Dynamics of Recreational Fishers in Port Phillip Bay, Australia}

\author{
Ali Jalali', Justin D. Bell' ${ }^{1}$, Harry K. Gorfine ${ }^{2 *}$, Simon Conron ${ }^{1}$ and Khageswor Giri ${ }^{3}$ \\ ${ }^{1}$ Victorian Fisheries Authority, Melbourne, VIC, Australia, ${ }^{2}$ The University of Melbourne, Parkville, VIC, Australia, ${ }^{3}$ Agriculture \\ Victoria Research, AgriBio Centre for AgriBioscience, Bundoora, VIC, Australia
}

Recreational fishing is a popular pastime and multibillion dollar industry in Australia, playing a key economic role, especially in regional areas. In the State of Victoria, Port Phillip Bay (PPB), bordered by Melbourne and its suburbs, is the largest of the State's marine recreational fisheries. At present, little is known about the spatial and temporal dimensions of angler travel from origins to destinations, and the applicability of such spatial knowledge in fisheries management. To address this lack of information we assessed spatiotemporal dynamics and patterns in fishing trips, based upon travel distances on land and water, to acquire insight into the spatial ranges over which anglers residing in various locations travel to fishing destinations in the environs of PPB. Data for each angler per fishing trip, from 6,035 boat-based creel surveys, collected at 20 boat ramps in PPB during a 10-year period from 2010 to 2019, were analyzed by applying geospatial modeling. Differences were observed in both land and water travel distance by region and popular target species, with anglers who launched from Bellarine region traveling further on land, and those who targeted snapper traveling further on water. It was also evident that most anglers resided within close proximity of PPB, often less than $50 \mathrm{~km}$, although some anglers traveled long distances across the State to access fishing locations, particularly when targeting snapper. This work further highlights the importance of spatially explicit approaches to inform fisheries management by identifying users across different landscape and seascape scales, and out-of-region or State fishing trips, which may especially impact coastal communities and benefit local businesses.

Keywords: recreational fishing, angler behavior, travel dynamics, spatial modeling, network analysis, fishing destination

\section{INTRODUCTION}

Recreational fishing is a popular pastime with profound socio-cultural impacts, and it contributes considerably to the world economy (Cisneros-Montemayor and Sumaila, 2010; Cooke et al., 2018; Hyder et al., 2018; Lewin et al., 2019). Globally, more than 100 million people participate in recreational fishing annually, landing $\sim 0.9$ million tonnes per annum with participation 
and catch rates differing substantially among countries (Pauly and Zeller, 2016; Freire et al., 2020). Although annual recreational landings are not large $(\sim 1 \%)$ compared to the commercial catch ( $>100$ million tonnes per year), value adding derived from recreational activities can create substantial economic onflows (Cisneros-Montemayor and Sumaila, 2010; Potts et al., 2020).

There has recently been concerted effort, mainly in the industrialized world, to develop comprehensive governance structures for recreational fisheries given that most people fishing today do so recreationally (Arlinghaus et al., 2015, 2019). Yet, the recreational fishing sector generally lags behind the commercial sector in their understanding of fisheries policy and management. This can be best redressed by involving recreational fishers in monitoring and decision-making processes and regulatory agencies can improve their engagement of anglers by gaining a better understanding of recreational fisher behavior (Hunt et al., 2013; van Poorten and Camp, 2019). The underpinning operational policy objective is to enable fishing stakeholder needs to be met whilst satisfying community expectations for sustainability and socio-economic benefits ${ }^{1}$, particularly within proximity of urbanized coastal areas that provide easy access to marine resources. This is of particular importance given that in Australia the amount of recreational catch may exceed commercial catch in highly populated coastal areas, or that angling may be the only, or dominant, recreational activity supporting tourism and holiday visitation within less populous areas (McPhee et al., 2002; McPhee, 2017). In this country, recreational fishing is very popular compared to global norms with $>19.5 \%$ of the population partaking, which is facilitated by highly efficient implementation of recreational fisheries policies and promotional initiatives (Cooke and Cowx, 2004; McPhee, 2017; Cooke et al., 2018; Lynch et al., 2019).

A major recreational fishing industry (i.e., tackle, bait, equipment, charter, and boat sales) exists in the State of Victoria and the direct and indirect economic output of its recreational fishing activities was estimated to be about AUD \$7.5 billion in 2018/19 arising from more than six million fishing trips, generating > 14,000 direct jobs (Huang et al., 2020; VFA, 2020). Centrally located in Victoria, Port Phillip Bay (PPB; Figure 1) is a large marine embayment bordered by Greater Melbourne and Geelong regions extending along the Mornington and Bellarine Peninsulas on its eastern and western sides, respectively (ASGS, 2021). Due to PPB's sheltered waters, diversity of habitats, and proximity to Melbourne and suburbs, with a population exceeding 4 million (ABS, 2016), recreational fishing is extremely popular. Thus, PPB plays a key role from both an urban and regional perspective because it creates numerous tourism and economic opportunities (Sampson et al., 2014). Although PPB supports diverse ecologically and economically important species, the main species of interest to recreational anglers are snapper (Pagrus auratus), southern calamari (Sepioteuthis australis), King George whiting (KGW) (Sillaginodes punctatus), and sand flathead (Platycephalus bassensis).

Little is known about angler behavior and travel characteristics within space and time in $\mathrm{PPB}$. Understanding angler behavior

${ }^{1}$ https://vfa.vic.gov.au/operational-policy; accessed 23/12/21. and responses to the implementation of varying policies and strategies is important due to the critical role that some anglers play in many aspects of fisheries governance (Fulton et al., 2011; Hunt et al., 2013; Camp et al., 2018; van Poorten and Camp, 2019). Spatial dynamics in fisheries resources, including spatiotemporal patterns in catch and effort have been widely investigated in fisheries science (McCluskey and Lewison, 2008; Stelzenmüller et al., 2008; Stewart et al., 2011; Post and Parkinson, 2012; Aidoo et al., 2015; Jalali et al., 2015, 2018). However, less attention has been devoted to the anglers' behavioral dimensions of their recreational fishing activities such as their travel distance, trip dynamics and fishing behaviors, largely due to the paucity of information available in most instances. This is of significance because the spatial context of the socioecological systems in which marine recreational fisheries operate can impose additional challenges to fisheries management and regulatory agencies due to heterogeneity of human uses and biological communities as well as key dynamic processes that maintain them (Pereira and Hansen, 2003; Carpenter and Brock, 2004; Crowder et al., 2006; Crowder and Norse, 2008; Lorenzen et al., 2010).

Economists and human geographers have traditionally used data from angler travel to assess the value of recreational fisheries and to evaluate the impacts of fishing on landscapes (Post et al., 2002, 2008; Hunt, 2005; Post and Parkinson, 2012). However, having a detailed understanding about the spatial dimensions of angler travel patterns is of further significance as it can assist to determine the spatial size, extent, and boundaries of areas targeted by anglers. Spatially explicit marine planning policies have been promulgated as a means for more effective fisheries management delivered at geographic scales that align with fish stock boundaries and varying demographics of anglers that harvest those stocks (Young et al., 2007; Pomeroy and Douvere, 2008; Klein et al., 2010; Lorenzen et al., 2010; Stelzenmüller et al., 2013; Camp et al., 2018). Spatially resolved approaches can more meaningfully engage stakeholders in decision making processes (Pomeroy and Berkes, 1997; Olsen et al., 2011), and the identification of the spatial origins of anglers targeting certain fishing grounds can foster effective allocation of resources. Moreover, given that the statistical properties of angler travel dynamics may differ considerably among target species, across regions, or through time, greater resolution can provide improved insights about how fishing effort distributes across landscapes and how it can contribute to local economies.

Challenges in understanding angler behavior stem from a lack of information which cannot be addressed in the absence of a comprehensive and well-structured monitoring program that acquires detailed multi-year data about travel dynamics. In this context, annual creel surveys collecting a variety of angler demographics and fishing behavior related data in PPB were undertaken. The primary objectives of this study were to use these data to estimate and describe anglers' travel distances from residential postcodes to boat ramps and from boat ramps to fishing locations, and to find out how these differ temporally, spatially and by target species, to assist resource managers and policymakers in making evidence-based decisions regarding recreational fisheries in PPB. 


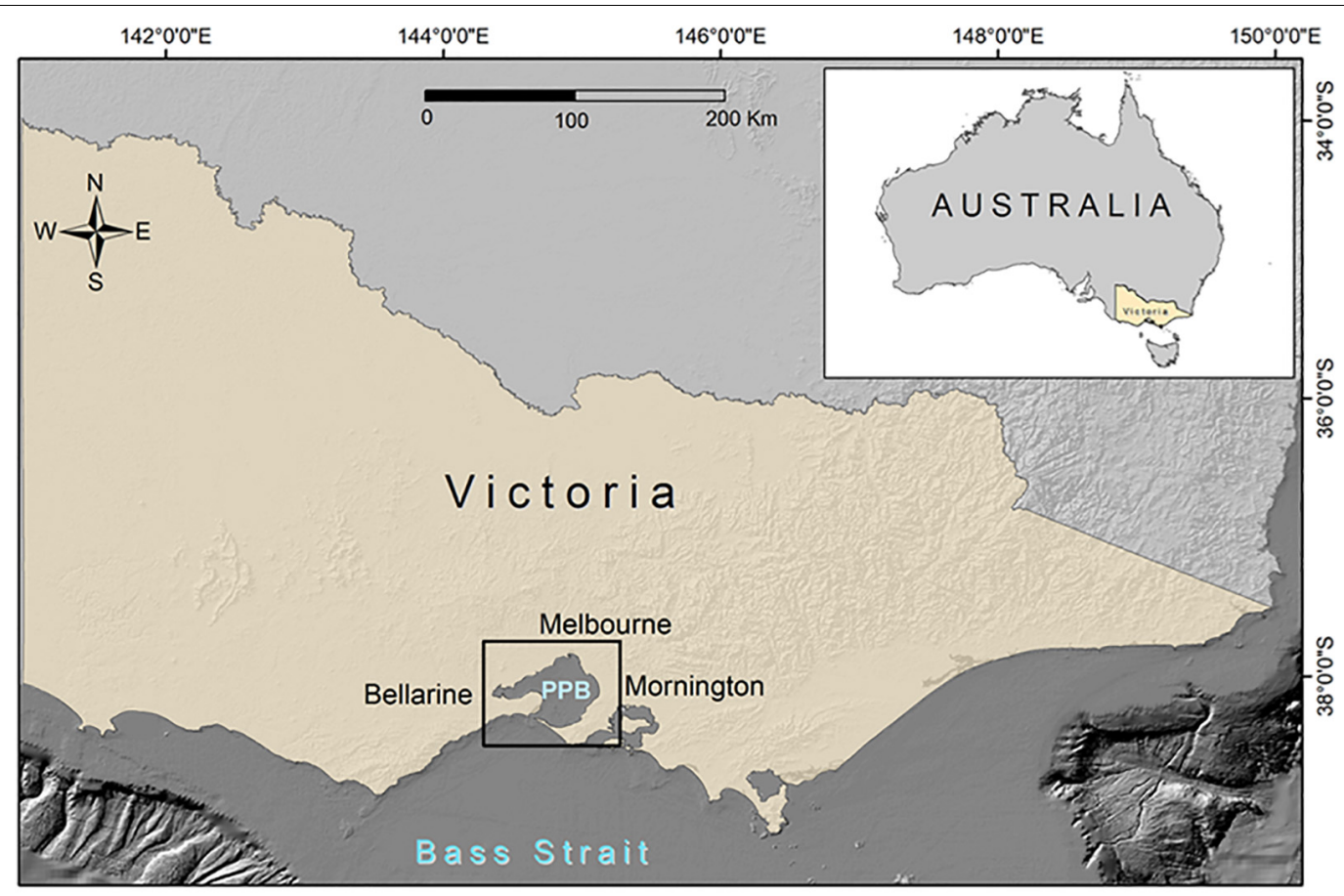

$144^{\circ} 20^{\circ} 0^{\circ} \mathrm{E}$

$144^{\circ} 40^{\circ} 0^{\circ} \mathrm{E}$

$145^{\circ} 0^{\circ} 0^{\circ} \mathrm{E}$

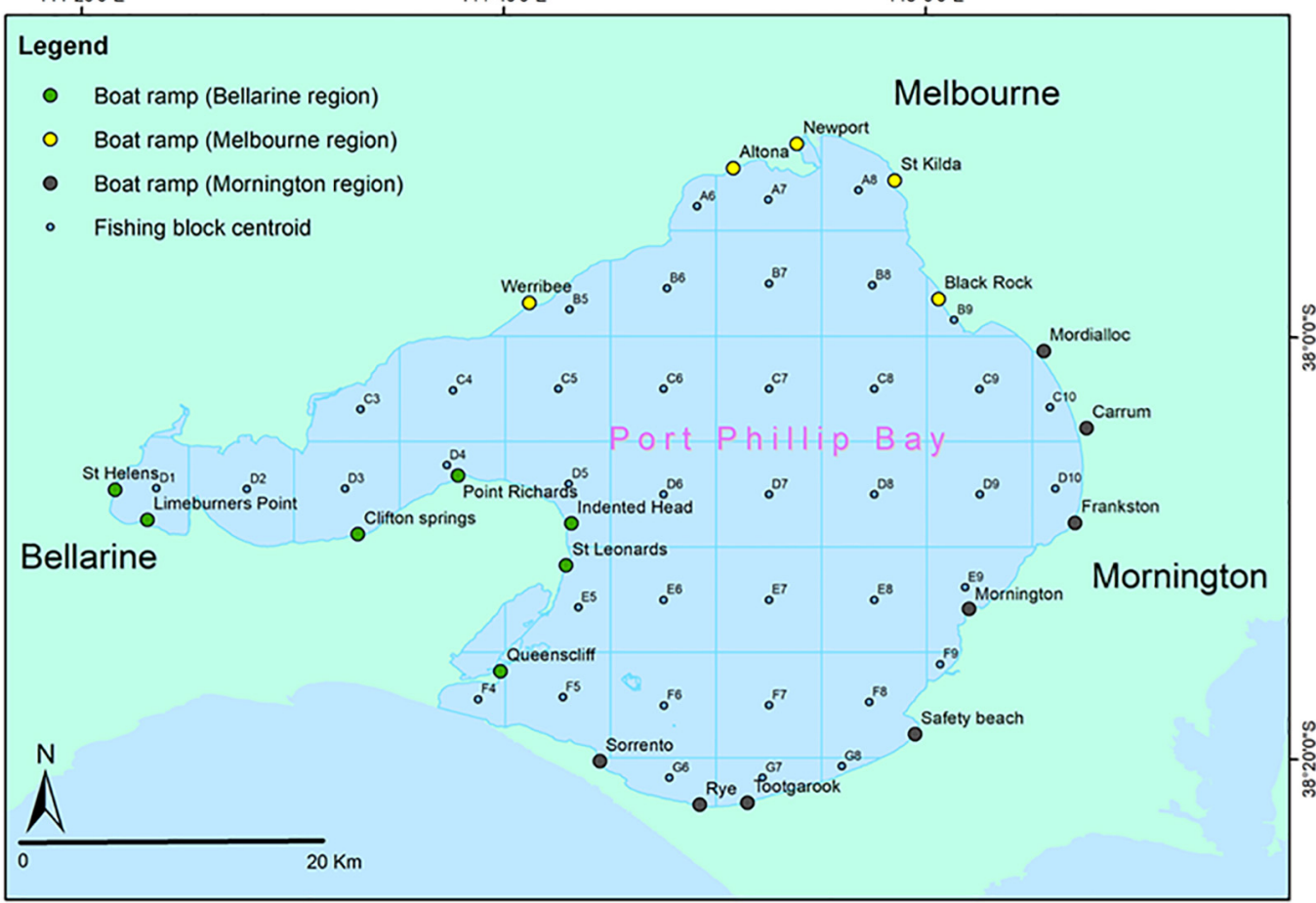

FIGURE 1 | Map of the study area overlaid across the shaded relief of land and sea, zoomed over the State of Victoria and Port Phillip Bay in the lower panel showing the three residential regions of Bellarine, Melbourne and Mornington. Fishing block codes and boat ramp names are also shown.

\section{MATERIALS AND METHODS}

\section{Survey Area}

Port Phillip Bay (PPB) is centrally located on the southern coastline of Victoria (Figure 1). It is a large marine embayment with an area of approximately $1,930 \mathrm{~km}^{2}$ and $264 \mathrm{~km}$ shoreline with an average depth of $13 \mathrm{~m}$, and the deepest part being $\sim 24 \mathrm{~m}$. PPB connects to Bass Strait through a narrow deep channel $(\sim 3.5 \mathrm{~km}$ across but up to nearly $100 \mathrm{~m}$ deep $\times 800 \mathrm{~m}$ wide at its most navigable passage) 
TABLE 1 | Fishing area and the proportion of anglers surveyed as well as the proportion of anglers in age groups for each fishing area based on 6,035 fishing trip records in Port Phillip Bay (Victoria) from 2010/2011 to 2018/19.

\begin{tabular}{|c|c|c|c|c|c|}
\hline \multirow[t]{2}{*}{ Region } & \multicolumn{4}{|c|}{ Proportion (\%) of anglers in each age group } & \multirow{2}{*}{$\begin{array}{c}\text { Proportion } \\
\quad(\%) \text { of } \\
\text { anglers }\end{array}$} \\
\hline & Age $<18$ & Age 18-49 & Age 50-69 & Age $\geq 70$ & \\
\hline Bellarine & 2.5 & 46.4 & 48.5 & 2.6 & 33.0 \\
\hline Melbourne & 5.4 & 63.3 & 27.4 & 3.9 & 36.3 \\
\hline Mornington & 3.7 & 69.2 & 26.6 & 0.5 & 30.7 \\
\hline
\end{tabular}

exchanging oceanic water (Holdgate et al., 2001; Sampson et al., 2014).

\section{Creel Survey Data}

Creel surveys of boat-based recreational fishing are conducted annually in PPB. The surveys are undertaken at 20 actively used boat ramps (i.e., Clifton Springs, Limeburners Point, St Leonards, Queenscliff, St Helens, Point Richards, Indented Head, Altona, Werribee, St Kilda, Newport, Black Rock, Carrum, Sorrento, Mornington, Rye, Mordialloc, Safety Beach, Frankston, Tootgarook) around PPB's coastline that can be divided into three regions (Melbourne, Bellarine and Mornington) based on geography and urbanicity (Table 1). The sampling design followed the approach described by Chen and Woolcock (1999) to ensure that estimates of fishing effort are unbiased. Creel surveys are conducted when anglers return from a fishing trip, mostly on weekends and during peak fishing days e.g., public holidays over a 6-month period (November to April), mainly to monitor harvest rates of key recreationally important species (Ryan and Conron, 2019). During survey interviews, anglers are asked to provide their residential postcode and information about their completed trip including fishing block, target species and the amount of time that they spent fishing, and if an angler changed their fishing block or target species during the fishing trip, then the main fishing block or target species was recorded. In this study, creel survey data were obtained from the years $2010 / 2011$ to $2018 / 19$ and only properly completed interviews with all questions answered were used for analyses. Most of the survey data (approximately 85\%) related to frequently targeted species: snapper, southern calamari, King George whiting (KGW), and flathead (Platycephalus spp.). Sand flathead and southern bluespotted flathead (Platycephalus speculator), were combined as "flathead" given that the two species are often caught concurrently and most anglers do not differentiate between them. Due to the limited number of fishing trips where other species were targeted, only the four abovementioned species were used to evaluate patterns and differences in travel distance. This resulted in 6,035 of the 7,495 fishing trip records being analyzed across three survey regions (i.e., Bellarine, Melbourne and Mornington) based on residential postcode.

Fishing blocks for each trip were assigned to one or more of 40 defined individually numbered rectangular fishing blocks (approximately $7 \mathrm{~km}$ by $9 \mathrm{~km}$ ) in PPB (Figure 1) in order to spatially resolve each angler's daily activity on water. Every vessel launched from a boat ramp in PPB was assumed to be capable of accessing any of the fishing blocks, yielding 800 potential alternative ramp-block and 1,600 block-block combinations from which each angler might choose (Huang et al., 2020).

\section{Spatial and Statistical Analyses Spatial}

The centroid of each angler's postcode polygon was generated in ArcGIS (version 10.7, ESRI) to provide proxies for anglers' residential postcode. Travel distance was calculated across two separate networks of land and water using the origindestination (OD) cost matrix in ArcGIS Network Analyst. The OD cost matrix identifies and measures the least-cost paths along the network from multiple origins to multiple destinations (Abrahamsson, 1998; Bera and Rao, 2011). To develop a land network, the Vicmap transport road network dataset ${ }^{2}$ for the state of Victoria was obtained to calculate land travel distance $(\mathrm{km})$ from each angler's residential postcode to the destination boat ramps. The origins in the road network were the nearest road to the centroid of each postcode polygon and the destinations were the boat ramp locations of the creel surveys. After creating origin-destination routes, results were validated by randomly selecting the network analysis outputs and comparing these with the Google Maps application, a web mapping service developed by Google as a reliable and popular mobile application for route planning ${ }^{3}$.

A waterway network across PPB was created with polylines connecting each boat ramp to the centroid of each fishing block, and fishing blocks collectively, as there were trip records with anglers targeting two or three fishing blocks, thereby enabling estimation of the entire distance traveled over water. Moreover, nautical charts and a light detection and ranging (LiDAR) bathymetric layer ( $5 \mathrm{~m}$ spatial resolution) were used to check that waterways were correctly defined through the navigable channels due to challenges in navigating some areas of PPB, particularly among sand shoals in its southern region. The OD cost matrix was also applied as per the land network to measure the travel distance on water, and to estimate distances traveled from the boat ramps to the centroid of targeted fishing blocks. The number of anglers from each postcode were spatially joined by their respective postcode polygon to generate a heatmap of angler distribution over the landscape.

\section{Statistical}

All statistical analysis were undertaken in $\mathrm{R}$ version 4.0.3 ( $\mathrm{R}$ Core Team, 2021). Multivariate analysis of non-metric multidimensional scaling (nMDS) was used to identify target species patterns among boat ramps. Data were square root transformed and then subjected to Wisconsin double standardization. A Bray-Curtis dissimilarity matrix was set for nMDS, and analyses were performed using the "vegan" package within the suite of R statistical software (Oksanen et al., 2020). Generalized linear models (GLM) were used to model differences in travel distance by region and target species on

\footnotetext{
${ }^{2}$ https://www.data.vic.gov.au/; accessed 20/03/2020.

${ }^{3}$ google.com/maps
} 


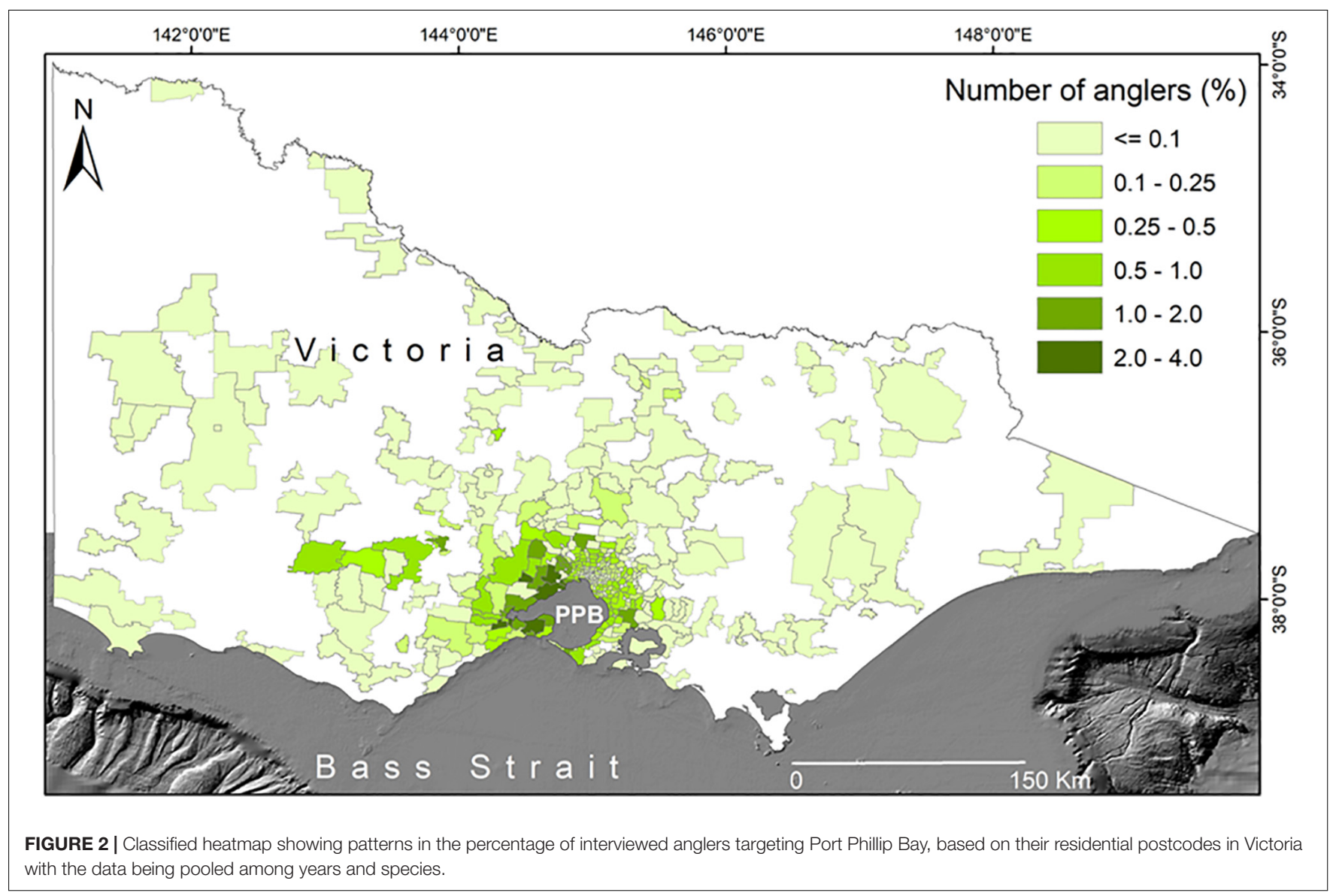

land and water. A Gaussian distribution was selected to best represent the distortion of the response variable with a log link function. The "ggplot2" data visualization package (Wickham, 2016) was applied to plot temporal (annual) trends in travel distance. In addition, regional and species differences in travel distance over land and water were evaluated using analysis of variance (ANOVA) and the non-parametric Kruskal-Wallis test, depending on the results of Shapiro-Wilk and Bartlett tests for normality and homogeneity of variance. Statistical differences in travel distance were then assessed between regions by applying post hoc Duncan and Wilcoxon tests at 95\% confidence intervals $(P<0.05)$.

\section{RESULTS}

Most anglers fishing in PPB were residents from postcodes within relatively close proximity of $\mathrm{PPB}$ particularly within Melbourne, Mornington and Southwest Victorian regions as well as Geelong, Bellarine and Surf Coast Shire (Figure 2). The number of anglers aboard each vessel varied widely, from one individual to 12 , with an average of 2.1 anglers per trip (Table 2). The amount of time spent fishing in PPB was $4.3 \pm 2.0$ (mean $\pm \mathrm{SD}$ ) hours on average per trip (Table 2), but there were a limited number of anglers (approximately one percent of fishing trips) who reportedly fished for considerably longer periods of
TABLE 2 | The average number of anglers per trip and average ( \pm SD) time spent fishing per trip in Port Phillip Bay by residential regions and overall.

\begin{tabular}{lcc}
\hline Region & Number of anglers per trip & Hours spent fishing \\
\hline Bellarine & 2.0 & $4.4 \pm 2.1$ \\
Melbourne & 2.1 & $4.5 \pm 2.0$ \\
Mornington & 2.1 & $4.1 \pm 1.9$ \\
Overall & 2.1 & $4.3 \pm 2.0$ \\
\hline
\end{tabular}

time. Although overnight trips are occasionally undertaken the veracity of these reports of extreme fishing duration is unknown. Variability in effort (time spent fishing) among the fishing blocks was high with anglers typically spending more time fishing in the central areas of PPB (Figure 3).

Regional patterns and variability in target species were evident in the nMDS with three clusters identified based on ordination of target species toward boat ramps within the three regions (Figure 4). Snapper were the dominant, or second most popular target species for anglers launching from most boat ramps, especially in the Melbourne and Mornington regions of PPB such as Carrum, Black Rock and Newport. This was followed by KGW and southern calamari, which were among the most popular target species for anglers who launched from the Bellarine and Mornington regions of PPB, particularly at Rye, Sorrento, Queenscliff and St Leonards boat ramps (Figure 4). 


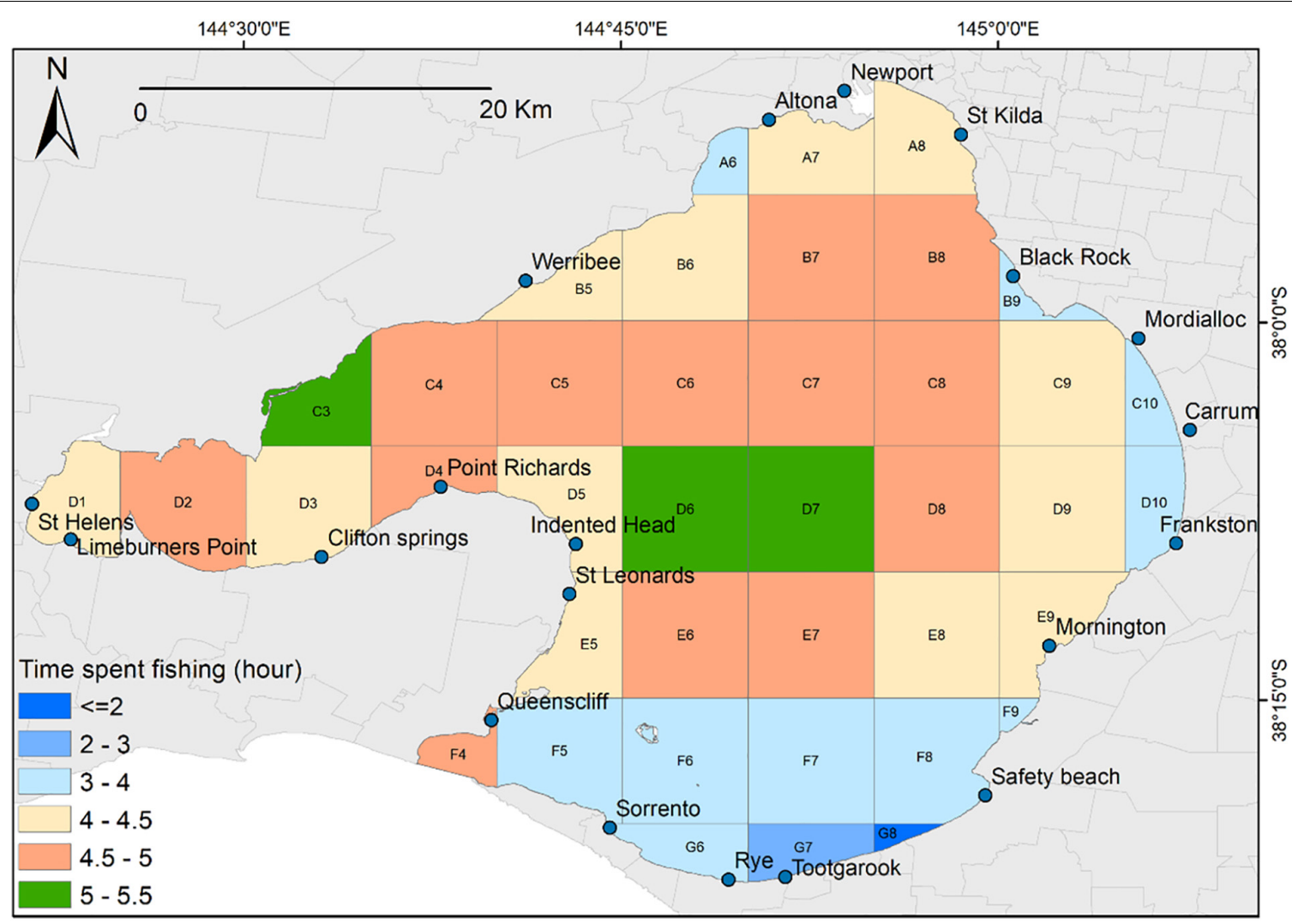

FIGURE 3 | Average amount of time (hours) spent fishing per fishing block in Port Phillip Bay based on the data pooled among years and species.

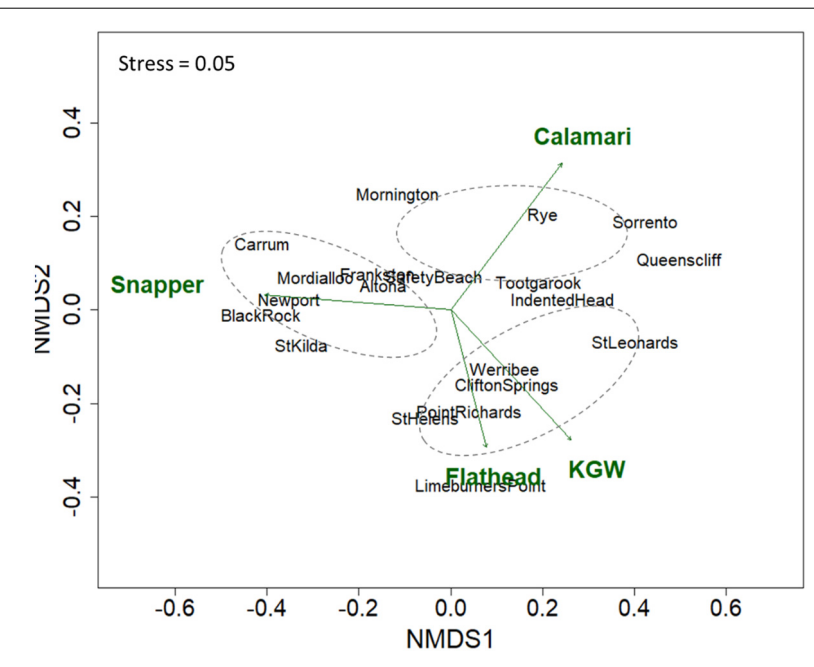

FIGURE 4 | Ordinations of nMDS analyses illustrating patterns of four main target species across boat ramps based on the survey data combined across years. Ellipses represent 95\% confidence intervals further indicating the clusters of boat ramps deriving patterns in target species.

Targeting of flatheads was more common at boat ramps located in the Bellarine region including Limeburners Point, St Helens and Point Richards. Assessment of anglers' travel distance and routes revealed that they traveled from throughout the State to fish in PPB (Figure 5). Spatial patterns in anglers' travel dynamics were related to target species with most fishing trips commencing from postcodes adjacent to PPB or from northern and western residential regions, especially by anglers targeting snapper. By calculating travel distance, we found that average distance traveled on land was $40.5 \mathrm{~km}$ per trip, ranging from about one $\mathrm{km}$ to over $580 \mathrm{~km}$, with most anglers residing within a proximity of about $50 \mathrm{~km}$ from their launch destination. Calculation of distance traveled on water with fishing trips starting from boat ramps to the centroid of fishing blocks showed that anglers traveled $11.1 \mathrm{~km}$ on average per trip one way.

The GLM results indicated significant differences by region and target species in travel distance on land and water $(P$ value $<0.001$, Table 3). Furthermore, anglers who launched from boat ramps in the Bellarine region traveled significantly longer distances on land to access PPB (Figure 6). In comparison, travel distance on water was significantly longer for anglers who launched from boat ramps in the Mornington and Melbourne regions (Figure 6).

In terms of travel distance by region and target species, we observed a significant increase in distance traveled via land by anglers who started their trip from the Bellarine region to target snapper (Table 3 and Figure 7). Similar regional differences were observed for other species (i.e., southern calamari, flathead and KGW) with longer distances traveled on land by anglers who 


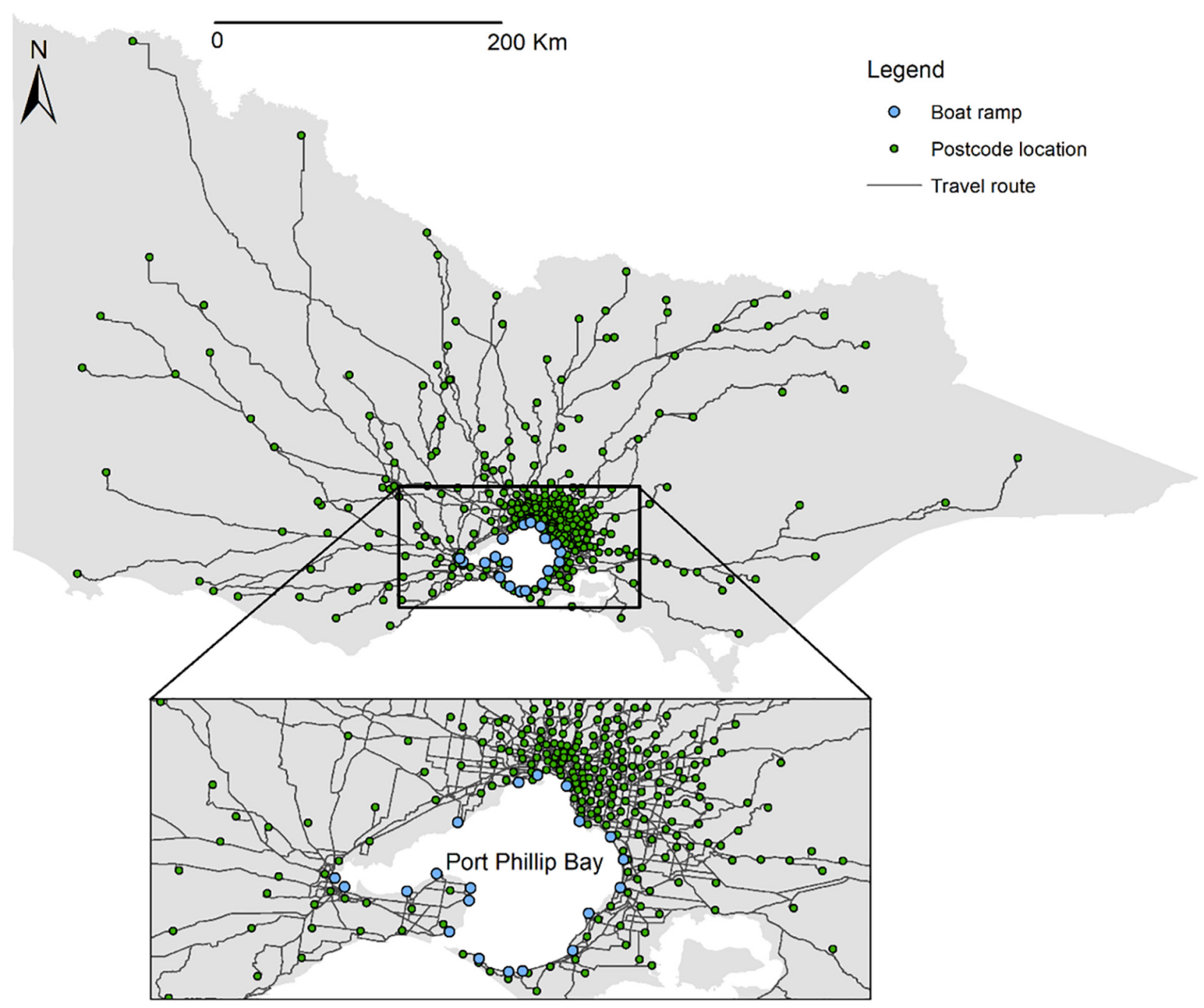

FIGURE 5 | Map showing land travel routes modeled using network analyst from residential postcodes of anglers to boat ramps throughout the State of Victoria. Data were pooled among species and years. Zoom box is drawn over Port Phillip Bay.

launched from boat ramps in the Bellarine region. In contrast, anglers who launched from boat ramps in the Melbourne and Mornington regions traveled significantly further on water for almost all target species (Table 3 and Figure 7). Longest travel distances on water occurred for snapper (14.3 km on average) by anglers from the Mornington region and the shortest fishing trips on water ( $7.2 \mathrm{~km}$ on average) were made by anglers who launched from the Bellarine region to target southern calamari.

Temporal (annual) assessment of travel distance on land and water revealed significant variation by region and target species. Travel distance on land increased through time in the Bellarine region, but the travel distance on water remained shorter compared to the Melbourne and Mornington regions (Figure 8). Relatively similar annual trends were evident when travel distance patterns were compared by region and target species (Figure 9), revealing longer travel distance on land, and shorter distance on water for anglers from Bellarine, though some trends did not appear to vary through time. Interestingly, an increasing annual trend in travel distance on water occurred for anglers launching from Mornington who targeted highly mobile snapper, whereas a decreasing annual trend in travel distance on water was detected for anglers launching from Melbourne who targeted southern calamari and flathead (Figure 9). There were clear consistencies in land and water travel distance trends for anglers from Melbourne and Mornington for flathead and KGW.

The most popular fishing trips by postcode to boat ramps and fishing blocks revealed over $80 \%$ of fishing trips were the same on water and about $50 \%$ the same via land (Figure 10). Most of the popular travel routes over land and water for snapper occurred in the east and north of PPB by anglers residing mostly in the Melbourne metropolitan area. Their fishing trips on water were predominately in the northern and eastern parts of PPB and ventured further into the deeper central areas of PPB (Figure 10). Different trip patterns on land and water were evident when anglers targeted calamari as most of these anglers were from postcodes in the west, north and southeast of $\mathrm{PPB}$, and most 
TABLE 3 | Summary statistics of generalized linear models (GLM) describing travel distance on land and water by region and species, and statistical differences in average travel distance $(\mathrm{km})$ on land and water between regions by target species in PPB.

\begin{tabular}{lcccc}
\hline \multicolumn{2}{l}{ Travel distance on land } & & & \\
\hline Variable & & Standard error & Deviance & $\boldsymbol{p}$-value \\
\hline Region & Melbourne & 0.039 & 994,956 & $<0.001$ \\
& Mornington & 0.033 & & \\
Species & Flathead & 0.041 & 228,068 & $<0.001$ \\
& KGW & 0.038 & &
\end{tabular}

Travel distance on water

\begin{tabular}{lcccc}
\hline Variable & & Standard error & Deviance & $\boldsymbol{p}$-value \\
\hline Region & Melbourne & 0.024 & 20,099 & $<0.001$ \\
& Mornington & 0.025 & & \\
Species & Flathead & 0.039 & 11,246 & $<0.001$ \\
& KGW & 0.038 & & \\
& Snapper & 0.030 & &
\end{tabular}

Average travel distance $(\mathrm{km})$ on land

\begin{tabular}{lccc}
\hline Species & \multicolumn{3}{c}{ Region } \\
\cline { 2 - 4 } & Bellarine & Melbourne & Mornington \\
\hline Snapper & $49.4^{\#}$ & $25.8^{\mathrm{ns}}$ & $29.6^{\mathrm{ns}}$ \\
Calamari & $68.8^{\#}$ & $27.7^{\star}$ & $54.7^{@}$ \\
Flathead & $60.0^{\#}$ & $31.7^{\mathrm{ns}}$ & $42.2^{\mathrm{ns}}$ \\
KGW & $58.3^{\#}$ & $28.9^{\mathrm{ns}}$ & $37.5^{\mathrm{ns}}$ \\
\hline
\end{tabular}

Average travel distance $(\mathbf{k m})$ on water

\begin{tabular}{lccc}
\hline Species & \multicolumn{3}{c}{ Region } \\
\cline { 2 - 4 } & Bellarine & Melbourne & Mornington \\
\hline Snapper & $11.1^{\#}$ & $13.1^{\mathrm{ns}}$ & $14.3^{\mathrm{ns}}$ \\
Calamari & $7.2^{\#}$ & $12.1^{\mathrm{ns}}$ & $9.4^{\mathrm{ns}}$ \\
Flathead & $7.9^{\#}$ & $11.4^{\mathrm{ns}}$ & $11.7^{\mathrm{ns}}$ \\
KGW & $7.8^{\#}$ & $12.5^{\mathrm{ns}}$ & $10.2^{\mathrm{ns}}$ \\
\hline
\end{tabular}

Data are based on anglers' average travel distance combined across years.

Different symbols (\#, *, and @) in each row indicate significant differences in travel distance between regions for the species in a given row at a $5 \%$ level of significance, with "ns" indicating differences among regions that were non-significant.

of their fishing trips occurred in shallow inshore waters in the south and western areas of PPB (Figure 10). In contrast, fishing trips targeting flathead and KGW were popular among anglers from postcodes from suburbs farther north and west of PPB (Figure 10), and fishing trips on water were also dominated in the north and west, with anglers who were targeting flathead generally traveling further into deeper water.

\section{DISCUSSION}

The present study has improved our understanding of marine recreational fishers' behavior in $\mathrm{PPB}$, including spatial and

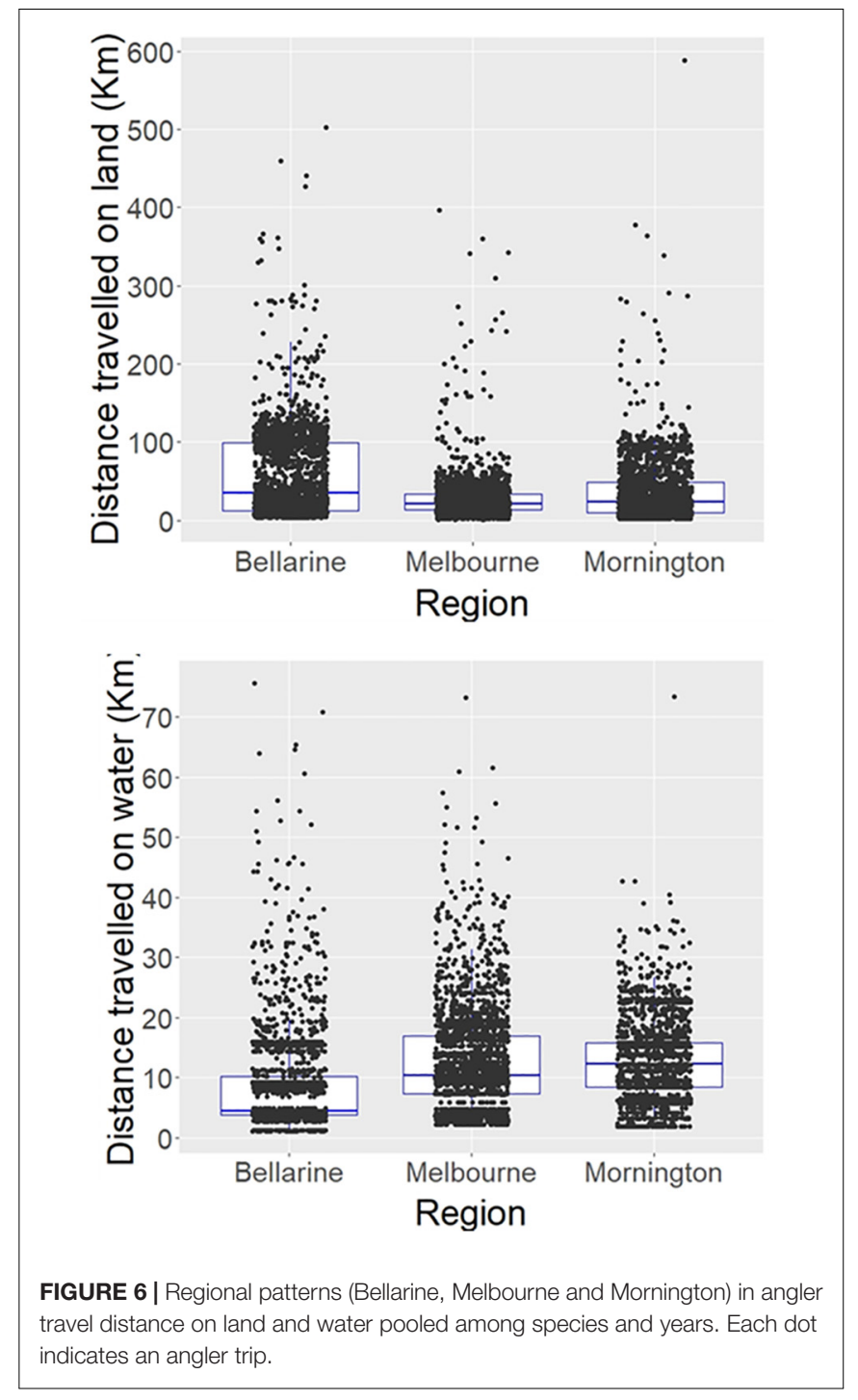

temporal attributes of distances traveled on land and water to target particular species. In many instances, travel patterns varied considerably based on all these factors. Such knowledge is useful for managers and policy makers as it identifies the boundaries as well as dimensions of the areas explored by resource users across seascape and landscape scales.

This kind of information has guided planning and implementation of recent initiatives to upgrade boat ramps by adding additional lanes and trailer parking bays, and to improve land-based facilities for anglers, such as fish cleaning tables, fish waste and tackle disposal bins, and boat washdown stations, at the more popular launching locations around PPB (Better Boating Victoria, 2021).

Spatial-based analysis and mapping are useful for better understanding the dynamics of recreational fishing trips because when the results are used in conjunction with stakeholder engagement, they can become a key component of successful fisheries co-management (Pomeroy and Berkes, 1997; Pomeroy and Douvere, 2008; Pınarbaşı et al., 2017). Particular attention 

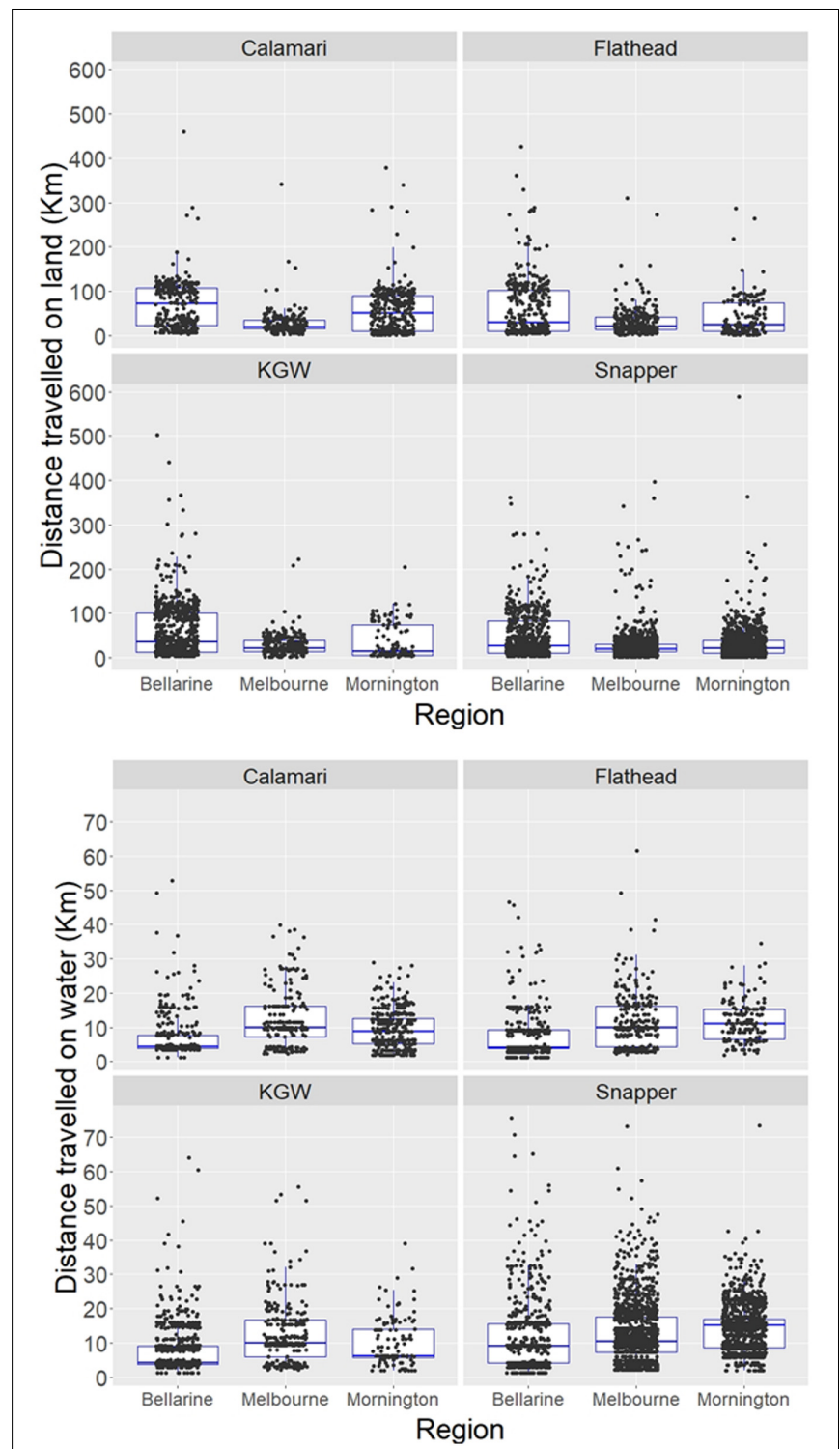

FIGURE 7 | Regional patterns (Bellarine, Melbourne and Mornington) in angler travel distance on land and water by individual key species in Port Phillip Bay combined across years. Each dot indicates an angler trip.

has been given to marine spatial planning in recent times, incorporating human activities, for supporting sustainable resource harvest and conservation (Douvere, 2008; Katsanevakis et al., 2011; Rassweiler et al., 2014; Domínguez-Tejo et al., 2016). In this respect, spatiotemporal assessment of anglers' trip and effort patterns may assist in achieving better user and stock support as some fisheries can transcend spatial boundaries, requiring coordination throughout land and water management areas. For instance, urban residents from Melbourne may travel further by land to target southern calamari and KGW in southern $\mathrm{PPB}$, which can concomitantly generate increased tourism-based spending in regional Victoria whilst imposing further pressure on stocks in those areas. A quantitative understanding of these dynamics will enable resource managers to incorporate these factors into future decision-making processes, which hitherto had not been possible.

In addition, model outputs and maps generated from spatial analyses can reflect the complexity and patterns in the distribution of anglers at local and out-of-region levels. This may help predict how the behavior of these users and its impact on resources change and evolve through space and time, which is not generally well understood in recreational fisheries. Some anglers, especially those who launched their vessels from boat ramps in the Bellarine region to fish the western parts of PPB, traveled longer distances on land throughout regional Victorian to reach fishing destinations. Given such differences, co-management strategies may also differ in how to effectively engage these users as, for example, it has been suggested that stakeholders who are local residents and reside in closer proximity to the resources they use may have a greater tendency to be involved in comanagement actions (Gutiérrez et al., 2011). Local users may also be more accessible and easier to engage, whereas more distant users from larger geographic scales may be less apt, or at least more difficult to engage in co-management activities (Hammitt et al., 2004; Cheng and Daniels, 2005; Hart et al., 2015). Distant users may also be less informed about fishing regulations and require different strategies to access information, noting that fishing regulations are provided on a mobile phone application that covers the entire State. In addition, local stakeholders may share more cohesive cognitions and have common preferences or requirements related to a given geographical region to produce greater resource stewardship in contrast to visitors from other residential regions. This may diverge even further between urban and regional residents, for instance, in terms of the levels of dependency, sentiments and attitudes toward local natural resources (Bonaiuto et al., 2002), as people may be more likely to support the protection of the local environment if they feel attached to a given geographic region or place (Faccioli et al., 2020). On the other hand, local people may not perceive resource protection initiatives, like MPAs, as useful, especially whenever a lack of access to former fishing grounds seems to impinge on community livelihood or managerial governance of MPAs is considered to be inadequate (Bennett and Dearden, 2014).

The present study has shown that, unsurprisingly, spatial patterns in anglers' fishing effort are linked to the target species' productivity and habitat preferences, as well as their mobility e.g., snapper (Hamer and Mills, 2017), under the assumption that the regions in which fishers are operating are more likely to support higher densities of targeted species. Herein, anglers launching from the Bellarine region were more likely to target KGW and calamari where seagrass and/or reef habitats are more abundant (see Mazor et al., 2021). Previous investigations of KGW habitat suitability indicated high suitability of the western and southern areas of PPB supporting seagrass or seagrass-edge habitats (Morris and Ball, 2006). Reduced fishing trips for KGW were evident in the central and eastern areas of PPB that are less suitable for KGW due to the deeper substratum and/or relatively bare sand habitat (Hamer et al., 2004; Morris and Ball, 2006).

Most fishing trips for southern calamari occurred adjacent to Rye, Sorrento, Queenscliff and to a lesser extent several other boat 

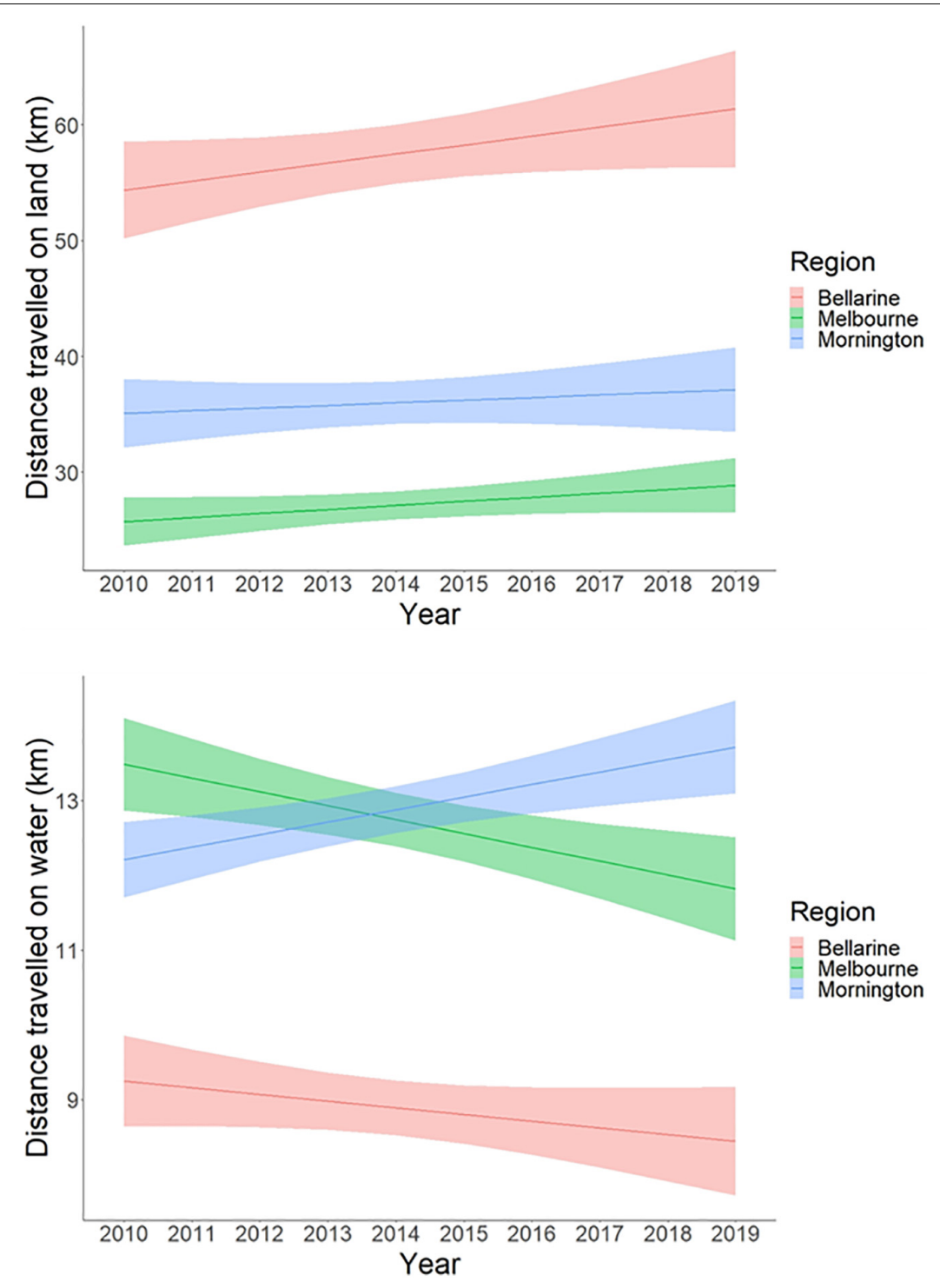

FIGURE 8 | GLM plots of temporal trends in the anglers' average travel distance $(\mathrm{km})$ on land and water by residential region, combined across species. Shaded areas represent the $95 \%$ confidence intervals.

ramps in Bellarine region. Southern calamari is a demersal species that inhabits shallow inshore waters aggregating on seagrass beds to spawn (Smith et al., 2015). Therefore, shallow reef structures and seagrass beds surrounding the edges of PPB are more likely to be of interest to anglers who do not generally need to travel long distances on water to reach their fishing spots, especially those launching from Bellarine region as was observed in travel distance modeling.

Flathead, as interpreted in the present study, represents an assemblage of species, which are a popular table fish with sand flathead being the most popular among them in PPB because they are easy to catch and delectable (Fishing World, 2021). Flathead also show much higher CPUE in PPB than the other main target species, including snapper and KGW (Conron et al., 2020). Flathead can occupy a range of habitats, being found in estuaries, on bare sandy, muddy and weedy bottoms as well as in deeper areas (Jordan, 2001; Imamura, 2015). Such behavior and habitat preferences could potentially address variability in anglers' effort patterns throughout PPB and longer distances traveled to facilitate access to intermediate and deep waters, where they are particularly abundant (Parry et al., 1995).

In contrast, anglers' trips and fishing effort for snapper were spread throughout PPB especially within fishing blocks in the deeper areas in the east and north where the majority of snapper spawn (Hamer and Mills, 2017). PPB is the center of recreational snapper fishing in Victoria, which is highly valued by anglers, and the snapper fishery in PPB varies both spatially and temporally (Hamer and Mills, 2017). In this respect, it has been demonstrated that preferred habitats of adult snapper 


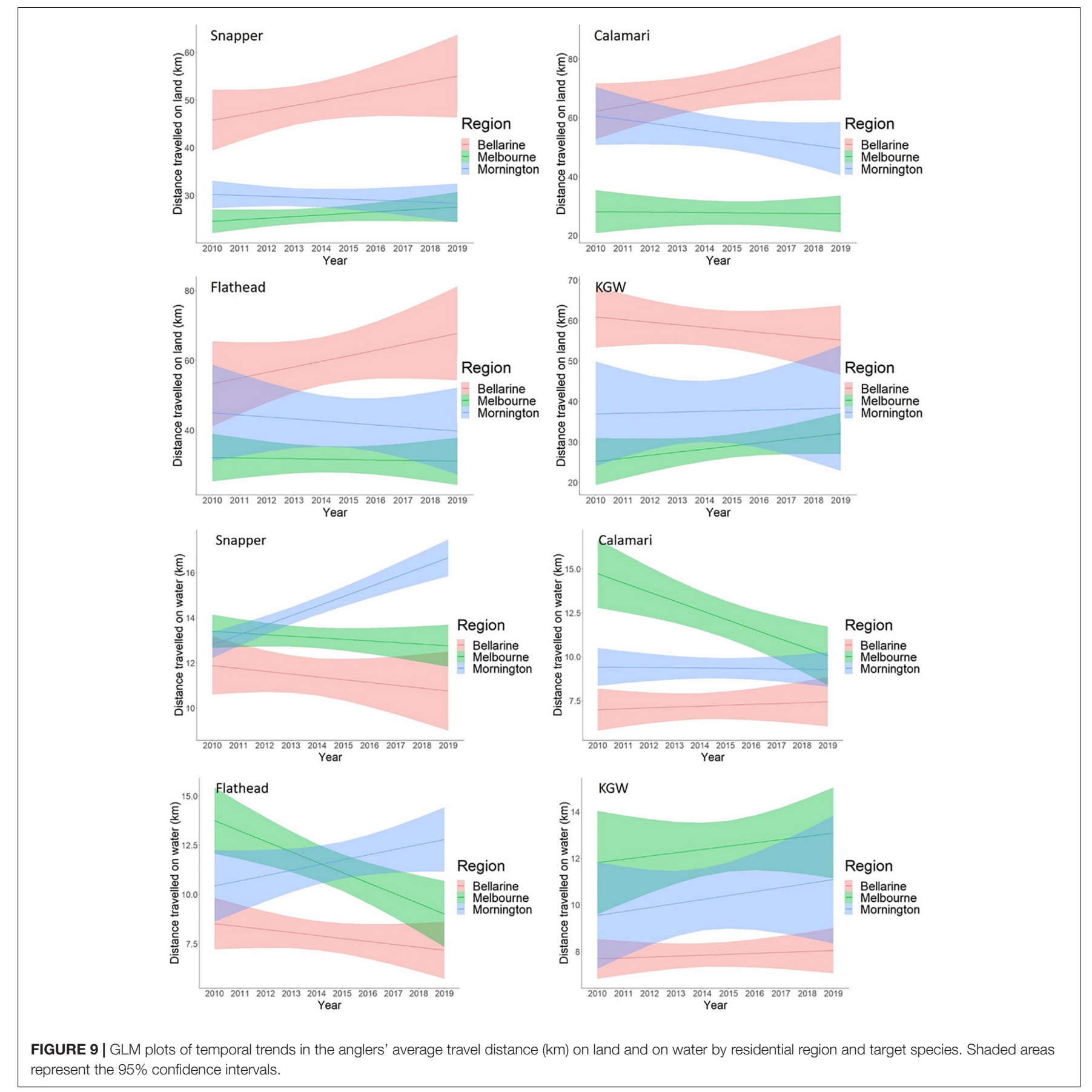

differ from sub-adult snapper, with the deeper areas being more favorable, whereas shallow seagrass habitat and substrates of coarser sediment less suitable for adult snapper and larger size/age groups (Morris and Ball, 2006). This species' habitat preference, in turn, influences anglers' fishing decisions and travel dynamics as revealed in the most popular trip maps with $>80 \%$ of fishing trips targeting fishing blocks in the north and east of PPB. Anglers targeting snapper traveled further than those targeting other species, both because snapper frequented deeper waters further from shore, and also because both sub-adult and adult snapper are aggregative and highly mobile, moving considerable distances utilizing a range of habitats (Wilson, 1986; Parry et al., 1995; Conron and Coutin, 1998; Hamer and Mills, 2017). Although spatial and temporal trends in fishing trips can be linked to suitable habitat for each target species, there could also be other factors at play such as travel time at sea and associated costs, suitability of vessels for long range travel, prevailing weather conditions, time constraints, anglers' knowledge, seafaring experience, and potentially others, that play a role in anglers' decisions and 

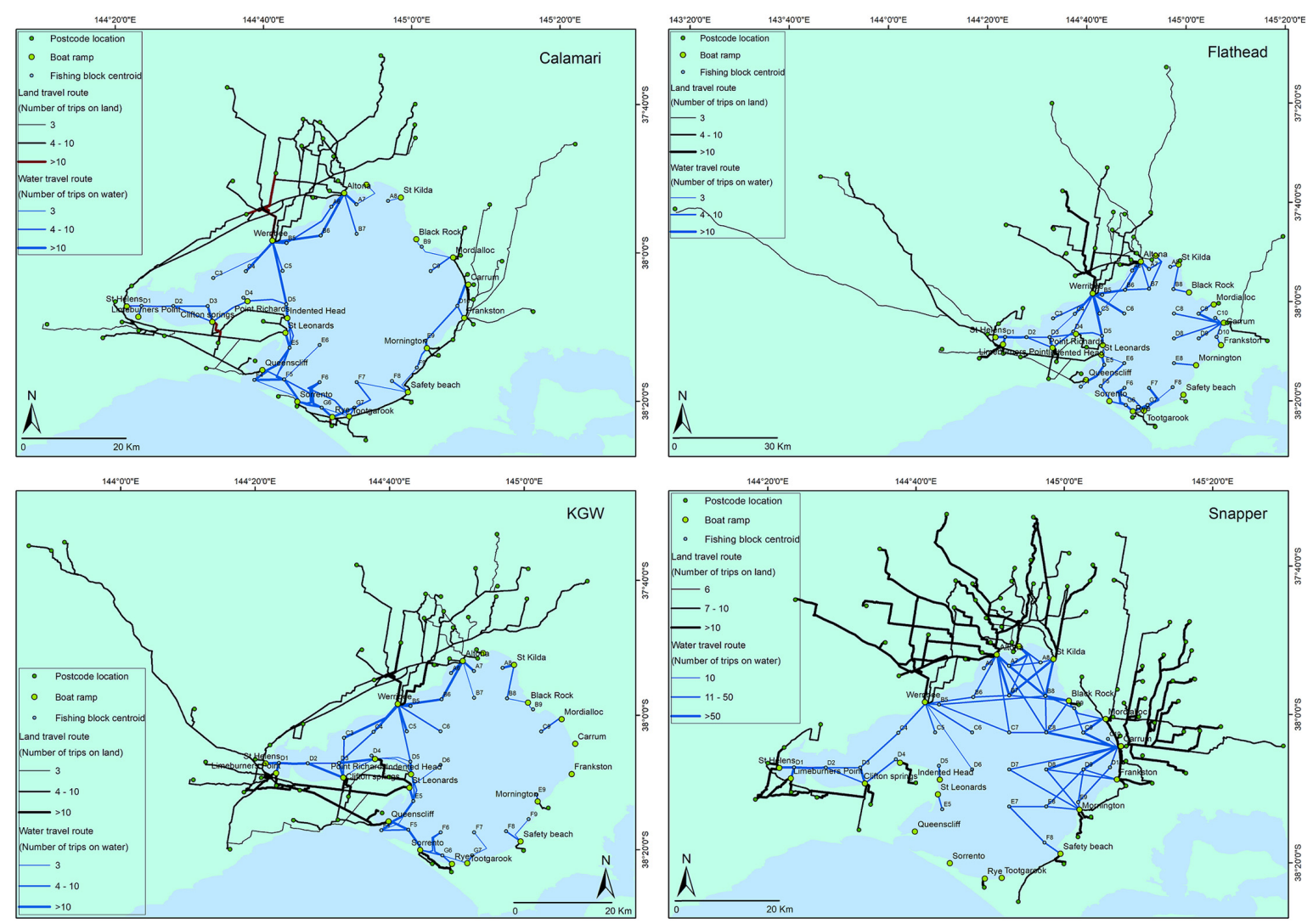

FIGURE 10 | Map of the most popular fishing trips over land and water (from residential postcode to the boat ramps and fishing blocks) to target the four main recreationally targeted species in Port Phillip Bay combined across years. These routes incorporate around $50 \%$ of all fishing trips on land, and over $80 \%$ of all fishing trips on water.

choices in fishing location. Nevertheless, both the number of anglers, and the time spent fishing, was relatively similar among years regardless of residential region, fishing block or target species, indicating that actual fishing time appears to be independent of travel time to and from the fishing grounds. Thus, it appears that this fishing time is sufficient to satisfy anglers expectations in terms of the overall experience, including the number of fish caught, or persistence if none are caught, and the need to allow sufficient time to return to shore, clean, pack up, and drive home.

Although we did not investigate angler travel patterns from economic perspectives, angler travel dynamics influences the spatial redistribution of their expenditure, which may support local businesses, further highlighting its importance to governing bodies, as has been revealed in other geographies such as Europe and United States (Steinback, 1999; Butler et al., 2009; Hyder et al., 2018; Pita et al., 2018). Given that millions of recreational fishing trips occur annually worldwide across diverse urban, regional and remote geographic regions to access convenient or prime fishing destinations, this pastime can create many direct and indirect job opportunities with substantial economic yield, which may be particularly important for the prosperity of coastal communities (McPhee, 2017; Camp et al., 2018; Pita et al., 2018). Impacts on local market activity will differ by species or region as all fisheries are unlikely to have the same potential spatial impact from the economic benefits derived from angling. It follows that economic investigations are required to provide policy makers with objective information obtained from comprehensive and robust analysis of angler demographics, expenditure patterns and socioeconomic dependencies of local and regional communities.

\section{DATA AVAILABILITY STATEMENT}

The de-identified raw data supporting the conclusions of this article will be made available by the authors, without undue reservation.

\section{ETHICS STATEMENT}

Ethical review and approval was not required for the study on human participants in accordance with the local legislation and institutional requirements. Written informed consent for participation was not required for this study in accordance with the national legislation and the institutional requirements. Ethical review and approval was not required for the animal study 
because no direct sampling of vertebrate animals or cephalopods was undertaken by the researchers.

\section{AUTHOR CONTRIBUTIONS}

SC conceived the study, supervised the data collection, and oversaw the drafting process. AJ was involved in all phases of design, analysis, interpretation, and writing. JB supervised the quantitative analysis, interpretation of the results and assisted with drafting and refining the text. HG helped with interpreting the results, drafting and refining the text, and preparing tables and figures for submission and KG selected the appropriate statistical analysis, interpreted the analytical outputs and helped to accurately describe these in the methods and

\section{REFERENCES}

Abrahamsson, T. (1998). Estimation of Origin-Destination Matrices Using Traffic Counts - A Literature Survey. IIASA Interim Report, IR-98-021. Laxenburg: IIASA, 32 .

ABS (2016). Australian Bureau of Statistics. 2016 Census QuickStats. Available online at: https://quickstats.censusdata.abs.gov.au/census_services/getproduct/ census/2016/quickstat/2GMEL. (accessed December 18, 2021)

Aidoo, E. N., Mueller, U., Goovaerts, P., and Hyndes, G. A. (2015). Evaluation of geostatistical estimators and their applicability to characterise the spatial patterns of recreational fishing catch rates. Fish. Res. 168, 20-32. doi: 10.1016/j. fishres.2015.03.013

Arlinghaus, R., Abbott, J. K., Fenichel, E. P., Carpenter, S. R., Hunt, L. M., Alós, J., et al. (2019). Opinion: governing the recreational dimension of global fisheries. Proc. Natl. Acad. Sci. U.S.A. 116, 5209-5213. doi: 10.1073/pnas.1902796116

Arlinghaus, R., Tillner, R., and Bork, M. (2015). Explaining participation rates in recreational fishing across industrialised countries. Fish. Manag. Ecol. 22, 45-55. doi: $10.1111 /$ fme. 12075

ASGS (2021). Australian Statistical Geography Standard (ASGS) Edition 3.A classification of Australia Into a Hierarchy of Statistical Areas for the Publication and Analysis of Official Statistics and Other Data. Available online at: https:/www.abs.gov.au/statistics/standards/australian-statistical-geographystandard-asgs-edition-3/jul2021-jun2026 (accessed December 18, 2021)

Bennett, N. J., and Dearden, P. (2014). Why local people do not support conservation: community perceptions of marine protected area livelihood impacts, governance and management in Thailand. Mar. Policy 44, 107-116. doi: 10.1016/j.marpol.2013.08.017

Bera, S., and Rao, K. V. K. (2011). Estimation of origin-destination matrix from traffic counts: the state of the art. Eur. Transport 49, 3-23.

Better Boating Victoria (2021). Charting the Course: Victorian Recreational Boating Strategy 2021-2030. Melbourne, VIC: Department of Transport, 60.

Bonaiuto, M., Carrus, G., Martorella, H., and Bonnes, M. (2002). Local identity processes and environmental attitudes in land use changes: the case of natural protected areas. J. Econ. Psychol. 23, 631-653. doi: 10.1016/S0167-4870(02) 00121-6

Butler, J. R. A., Radford, A., Riddington, G., and Laughton, R. (2009). Evaluating an ecosystem service provided by Atlantic salmon, sea trout and other fish species in the River Spey, Scotland: the economic impact of recreational rod fisheries. Fish. Res. 96, 259-266. doi: 10.1016/j.fishres.2008.12.006

Camp, E. V., Ahrens, R. N. M., Crandall, C., and Lorenzen, K. (2018). Angler travel distances: implications for spatial approaches to marine recreational fisheries governance. Mar. Policy 87, 263-274. doi: 10.1016/j.marpol.2017. 10.003

Carpenter, S. R., and Brock, W. A. (2004). Spatial complexity, resilience and policy diversity: fishing on lake-rich landscapes. Ecol. Soc. 9:8.

Chen, S. X., and Woolcock, J. L. (1999). A condition for designing bus-route type access site surveys to estimate recreational fishing effort. Biometrics 55, 799-804. doi: 10.1111/j.0006-341X.1999.00799.x results. All authors contributed to the article and approved the submitted version.

\section{FUNDING}

This Project was funded by Victorian Fisheries Authority and Recreational Fishing Licence Revenue from the Recreational Fishing Licence Trust Account.

\section{ACKNOWLEDGMENTS}

We would like to thank all recreational fishers and colleagues who contributed to the creel surveys over the last decade.

Cheng, A. S., and Daniels, S. E. (2005). Getting to 'we': examining the relationship between geographic scale and ingroup emergence in collaborative watershed planning. Hum. Ecol. Rev. 12, 30-43.

Cisneros-Montemayor, A. M., and Sumaila, U. R. (2010). A global estimate of benefits from ecosystem-based marine recreation: potential impacts and implications for management. J. Bioecon. 12, 245-268. doi: 10.1007/s10818010-9092-7

Conron, S., and Coutin, P. (1998). The Recreational Snapper Catch From Port Phillip Bay: A Pilot Survey of the Boat Based Fishery 1994/95. MAFRI Internal Report, 11. Queenscliff, VIC: Marine and Freshwater Resources Institute, 22.

Conron, S. D., Bell, J. D., Ingram, B. A., and Gorfine, H. K. (2020). Review of key Victorian fish stocks - 2019. Victorian Fisheries Authority Science Report Series No. 15, 1st Edn. Victorian Fisheries Authority, Queenscliff, VIC, 176.

Cooke, S. J., and Cowx, I. G. (2004). The role of recreational fishing in global fish crises. Bioscience 54, 857-859. doi: 10.1641/0006-3568(2004)054[0857:trorfi]2. $0 . \operatorname{co} ; 2$

Cooke, S. J., Twardek, W. M., Lennox, R. J., Zolderdo, A. J., Bower, S. D., Gutowsky, L. F. G., et al. (2018). The nexus of fun and nutrition: recreational fishing is also about food. Fish Fish. 19, 201-224. doi: 10.1111/faf.12246

Crowder, L., and Norse, E. (2008). Essential ecological insights for marine ecosystem-based management and marine spatial planning. Mar. Policy 32, 772-778. doi: 10.1016/j.marpol.2008.03.012

Crowder, L. B., Osherenko, G., Young, O. R., Airamé, S., Norse, E. A., Baron, N., et al. (2006). Resolving Mismatches in U.S. Ocean Governance. Science 313, 617-618. doi: 10.1126/science.1129706

Domínguez-Tejo, E., Metternicht, G., Johnston, E., and Hedge, L. (2016). Marine Spatial Planning advancing the Ecosystem-Based Approach to coastal zone management: a review. Mar. Policy 72, 115-130. doi: 10.1016/j.marpol.2016. 06.023

Douvere, F. (2008). The importance of marine spatial planning in advancing ecosystem-based sea use management. Mar. Policy 32, 762-771. doi: 10.1016/ j.marpol.2008.03.021

Faccioli, M., Czajkowski, M., Glenk, K., and Martin-Ortega, J. (2020). Environmental attitudes and place identity as determinants of preferences for ecosystem services. Ecol. Econ. 174:106600. doi: 10.1016/j.ecolecon.2020.106600

Fishing World (2021). Victorian Fisheries: Best Sand Flathead Spawning in Two Decades for Port Phillip. Available online at: https://www.fishingworld.com.au/ news/victorian-fisheries-best-sand-flathead-spawning-in-two-decades-forport-phillip (accessed May 27, 2021)

Freire, K. M. F., Belhabib, D., Espedido, J. C., Hood, L., Kleisner, K. M., Lam, V. W. L., et al. (2020). Estimating global catches of marine recreational fisheries. Front. Mar. Sci. 7:12. doi: 10.3389/fmars.2020.00012

Fulton, E. A., Smith, A. D. M., Smith, D. C., and van Putten, I. E. (2011). Human behaviour: the key source of uncertainty in fisheries management. Fish Fish. 12, 2-17. doi: 10.1111/j.1467-2979.2010.00371.x

Gutiérrez, N. L., Hilborn, R., and Defeo, O. (2011). Leadership, social capital and incentives promote successful fisheries. Nature 470, 386-389. doi: 10.1038/ nature09689 
Hamer, P., and Mills, K. (2017). Anglers Tune in to Find Out Why Port Phillip Bay is so Important to Snapper. Recreational Fishing Grants Program Research Report. Melbourne, VIC: Victorian Government, 94.

Hamer, P. A., Jenkins, G. P., and Sivakumaran, K. (2004). ). Identifying the Spawning Locations of King George Whiting in Victorian Waters: A Recreational Fishing Based Study. Fisheries Victoria, Research Report Series No. 21. Queenscliff, VIC: Department of Primary Industries, 26.

Hammitt, W. E., Backlund, E. A., and Bixler, R. D. (2004). Experience use history, place bonding and resource substitution of trout anglers during recreation engagements. J. Leisure Res. 36, 356-378. doi: 10.1080/00222216.2004.11950028

Hart, P. S., Stedman, R. C., and McComas, K. A. (2015). How the physical proximity of climate mitigation projects influences the relationship between affect and public support. J. Environ. Psychol. 43, 196-202. doi: 10.1016/j.jenvp. 2015.07.003

Holdgate, G. R., Geurin, B., Wallace, M. W., and Gallagher, S. J. (2001). Marine geology of Port Phillip, Victoria. Austr. J. Earth Sci. 48, 439-455. doi: 10.1046/j. 1440-0952.2001.00871.x

Huang, B., Young, M. A., Carnell, P. E., Conron, S., Ierodiaconou, D., Macreadie, P. I., et al. (2020). Quantifying welfare gains of coastal and estuarine ecosystem rehabilitation for recreational fisheries. Sci. Total Environ. 710:134680. doi: 10.1016/j.scitotenv.2019.134680

Hunt, L. M. (2005). Recreational fishing site choice models: insights and future opportunities. Hum. Dimens. Wildl. 10, 153-172. doi: 10.1080/ 10871200591003409

Hunt, L. M., Sutton, S. G., and Arlinghaus, R. (2013). Illustrating the critical role of human dimensions research for understanding and managing recreational fisheries within a social-ecological system framework. Fish. Manag. Ecol. 20, 111-124. doi: 10.1111/j.1365-2400.2012.00870.x

Hyder, K., Weltersbach, M. S., Armstrong, M., Ferter, K., Townhill, B., Ahvonen, A., et al. (2018). Recreational sea fishing in Europe in a global contextparticipation rates, fishing effort, expenditure, and implications for monitoring and assessment. Fish Fish. 19, 225-243. doi: 10.1111/faf.12251

Imamura, H. (2015). Taxonomic revision of the flathead fish genus Platycephalus Bloch, 1785 (Teleostei: Platycephalidae) from Australia, with description of a new species. Zootaxa 3904, 141-207. doi: 10.11646/zootaxa.3904.2.1

Jalali, A., Young, M., Huang, Z., Gorfine, H., and Ierodiaconou, D. (2018). Modelling current and future abundances of benthic invertebrates using bathymetric LiDAR and oceanographic variables. Fish. Oceanogr. 27, 587-601. doi: $10.1111 /$ fog. 12280

Jalali, M. A., Ierodiaconou, D., Gorfine, H., Monk, J., and Rattray, A. (2015). Exploring spatiotemporal trends in commercial fishing effort of an abalone fishing zone: a GIS-based hotspot model. PLoS One 10:e0122995. doi: 10.1371/ journal.pone.0122995

Jordan, A. R. (2001). Reproductive biology, early life-history and settlement distribution of sand flathead (Platycephalus bassensis) in Tasmania. Mar. Freshw. Res. 52, 589-601. doi: 10.1071/MF99155

Katsanevakis, S., Stelzenmüller, V., South, A., Sørensen, T. K., Jones, P. J. S., Kerr, S., et al. (2011). Ecosystem-based marine spatial management: review of concepts, policies, tools, and critical issues. Ocean Coast. Manag. 54, 807-820. doi: 10.1016/j.ocecoaman.2011.09.002

Klein, C. J., Steinback, C., Watts, M., Scholz, A. J., and Possingham, H. P. (2010). Spatial marine zoning for fisheries and conservation. Front. Ecol. Environ. 8:349-353. doi: 10.1890/090047

Lewin, W.-C., Weltersbach, M. S., Ferter, K., Hyder, K., Mugerza, E., Prellezo, R., et al. (2019). Potential environmental impacts of recreational fishing on marine fish stocks and ecosystems. Rev. Fish. Sci. Aquac. 27, 287-330. doi: 10.1080/23308249.2019.1586829

Lorenzen, K., Steneck, R. S., Warner, R. R., Parma, A. M., Coleman, F. C., and Leber, K. M. (2010). The spatial dimensions of fisheries: putting it all in place. Bull. Mar. Sci. 86, 169-177.

Lynch, T. P., Smallwood, C. B., Ochwada-Doyle, F. A., Lyle, J., Williams, J., Ryan, K. L., et al. (2019). A cross continental scale comparison of Australian offshore recreational fisheries research and its applications to marine park and fisheries management. ICES J. Mar. Sci. 77, 1190-1205. doi: 10.1093/icesjms/fsz092

Mazor, T., Edmunds, M., Flynn, A., and Ferns, L. (2021). Port Phillip Bay Habitat Map. Habitat Complex Modelling (CBiCS Level 3). The State of Victoria Department Environment, Land, Water and Planning 2021. 14. Available online at: https://www.marineandcoasts.vic.gov.au/_data/assets/pdf_file/
0031/537169/Mazor-et-al-2021_Port-Phillip-Bay-CBiCS-Habitat-Model.pdf (accessed December 21, 2021)

McCluskey, S. M., and Lewison, R. L. (2008). Quantifying fishing effort: a synthesis of current methods and their applications. Fish Fish. 9, 188-200. doi: 10.1111/j. 1467-2979.2008.00283.x

McPhee, D., Leadbitter, D., and Skilleter, G. A. (2002). Swallowing the bait: is recreational fishing in Australia ecologically sustainable? Pac. Conserv. Biol. 8, 40-51. doi: 10.1071/PC020040

McPhee, D. P. (2017). Urban recreational fisheries in the Australian coastal zone: the sustainability challenge. Sustainability 9:422. doi: 10.3390/su9030422

Morris, L., and Ball, D. (2006). Habitat suitability modelling of economically important fish species with commercial fisheries data. ICES J. Mar. Sci. 63, 1590-1603. doi: 10.1016/j.icesjms.2006.06.008

Oksanen, J., Blanchet, F. G., Friendly, M., Kindt, R., Legendre, P., McGlinn, D., et al. (2020). vegan: Community Ecology Package. R Package Version 2.5-7. Available online at: https://CRAN.R-project.org/package=vegan (accessed November 28, 2020).

Olsen, E., Kleiven, A. R., Skjoldal, H. R., and von Quillfeldt, C. H. (2011). Placebased management at different spatial scales. J. Coast. Conserv. 15, 257-269. doi: 10.1007/s11852-010-0108-1

Parry, G. D., Hobday, D. K., Currie, D. R., Officer, R. A., and Gason, A. S. (1995). The Distribution, Abundance and Diets of Demersal Fish in Port Phillip Bay. CSIRO Port Phillip Bay Environmental Study Technical Report, 21. Queenscliff, VIC: Victorian Fisheries Research Institute, 107.

Pauly, D., and Zeller, D. (2016). Catch reconstructions reveal that global marine fisheries catches are higher than reported and declining. Nat. Commun. 7:10244. doi: $10.1038 /$ ncomms 10244

Pereira, D. L., and Hansen, M. J. (2003). A perspective on challenges to recreational fisheries management: summary of the symposium on active management of recreational fisheries. North Am. J. Fish. Manag. 23, 1276-1282. doi: 10.1577/ M01-234

Pınarbaşı, K., Galparsoro, I., Borja, Á, Stelzenmüller, V., Ehler, C. N., and Gimpel, A. (2017). Decision support tools in marine spatial planning: present applications, gaps and future perspectives. Mar. Policy 83, 83-91. doi: 10.1016/ j.marpol.2017.05.031

Pita, P., Hyder, K., Gomes, P., Pita, C., Rangel, M., Veiga, P., et al. (2018). Economic, social and ecological attributes of marine recreational fisheries in Galicia, Spain. Fish. Res. 208, 58-69. doi: 10.1016/j.fishres.2018.07.014

Pomeroy, R., and Douvere, F. (2008). The engagement of stakeholders in the marine spatial planning process. Mar. Policy 32, 816-822. doi: 10.1016/j.marpol. 2008.03.017

Pomeroy, R. S., and Berkes, F. (1997). Two to tango: the role of government in fisheries co-management. Mar. Policy 21, 465-480. doi: 10.1016/S0308597X(97)00017-1

Post, J. R., and Parkinson, E. A. (2012). Temporal and spatial patterns of angler effort across lake districts and policy options to sustain recreational fisheries. Can. J. Fish. Aquat. Sci. 69, 321-329. doi: 10.1139/ f2011-163

Post, J. R., Persson, L., Parkinson, E. A., and Kooten, T. V. (2008). Angler numerical response across landscapes and the collapse of freshwater fisheries. Ecol. Appl. 18, 1038-1049. doi: 10.1890/07-0465.1

Post, J. R., Sullivan, M., Cox, S., Lester, N. P., Walters, C. J., Parkinson, E. A., et al. (2002). Canada's recreational fisheries: the invisible collapse? Fisheries 27, 6-17. doi: 10.1577/1548-84462002027<0006:CRF<2.0.CO;2

Potts, W. M., Downey-Breedt, N., Obregon, P., Hyder, K., Bealey, R., and Sauer, W. H. H. (2020). What constitutes effective governance of recreational fisheries? - a global review. Fish Fish. 21, 91-103. doi: 10.1111/faf.12417

Rassweiler, A., Costello, C., Hilborn, R., and Siegel, D. A. (2014). Integrating scientific guidance into marine spatial planning. Proc. R. Soc. B Biol. Sci. 281:20132252. doi: 10.1098/rspb.2013.2252

R Core Team (2021). R: A Language and Environment for Statistical Computing. Vienna: R Foundation for Statistical Computing.

Ryan, K. L., and Conron, S. C. (2019). Comparing indicators of recreational fishing in Port Phillip Bay, Australia, from 2008 to 2011 with variability from a background period (2003-07). Mar. Freshw. Res. 70, 1345-1357. doi: 10.1071/ MF18346

Sampson, J., Easton, A., and Singh, M. (2014). "Port Phillip Bay," in 'Estuaries of Australia in 2050 and Beyond', ed. E. Wolanski (Dordrecht: Springer), 49-68. 
Smith, T. M., Green, C. P., and Sherman, C. D. H. (2015). Patterns of connectivity and population structure of the southern calamary (Sepioteuthis australis) in southern Australia. Mar. Freshw. Res. 66, 942-947. doi: 10.1071/MF1 4328

Steinback, S. R. (1999). Regional economic impact assessments of recreational fisheries: an application of the IMPLAN modeling system to marine party and charter boat fishing in maine. North Am. J. Fish. Manag. 19, 724-736. doi: 10.1577/1548-8675(1999)019<0724:REIAOR>2.0.CO;2

Stelzenmüller, V., Lee, J., South, A., Foden, J., and Rogers, S. I. (2013). Practical tools to support marine spatial planning: a review and some prototype tools. Mar. Policy 38, 214-227. doi: 10.1016/j.marpol.2012. 05.038

Stelzenmüller, V., Maynou, F., Bernard, G., Cadiou, G., Camilleri, M., Crec'hriou, R., et al. (2008). Spatial assessment of fishing effort around European marine reserves: implications for successful fisheries management. Mar. Pollut. Bull. 56, 2018-2026. doi: 10.1016/j.marpolbul.2008. 08.006

Stewart, K. R., Lewison, R. L., Dunn, D. C., Bjorkland, R. H., Kelez, S., Halpin, P. N., et al. (2011). Characterizing fishing effort and spatial extent of coastal fisheries. PLoS ONE 5:e14451. doi: 10.1371/journal.pone.0014451

van Poorten, B. T., and Camp, E. V. (2019). Addressing challenges common to modern recreational fisheries with a buffet-style landscape management approach. Rev. Fish. Sci. Aquac. 27, 393-416. doi: 10.1080/23308249.2019. 1619071

VFA (2020). The Economic Value of Recreational Fishing in Victoria. Ernst and Young for the Victorian Fisheries Authority (VFA), 53. Melbourne. https://vfa.vic.gov.au/_data/assets/pdf_file/0004/629257/The-economic- value- of-recreational-fishing-in-Victoria-2020-Ernst-and-Young-Report.pdf (accessed December 18, 2021).

Wickham, H. (2016). ggplot2: Elegant Graphics for Data Analysis. New York, NY: Springer-Verlag, 213.

Wilson, G. (1986). Snapper. When, Where and How to Catch Them. A Guide to Port Phillip and Westernport Bay. Geelong, VIC: Geoff Wilson, 104.

Young, O. R., Osherenko, G., Ekstrom, J., Crowder, L. B., Ogden, J., Wilson, J. A., et al. (2007). Solving the crisis in ocean governance: place-based management of marine ecosystems. Environ. Sci. Policy Sustain. Dev. 49, 20-32. doi: 10.3200/ ENVT.49.4.20-33

Conflict of Interest: The authors declare that the research was conducted in the absence of any commercial or financial relationships that could be construed as a potential conflict of interest.

Publisher's Note: All claims expressed in this article are solely those of the authors and do not necessarily represent those of their affiliated organizations, or those of the publisher, the editors and the reviewers. Any product that may be evaluated in this article, or claim that may be made by its manufacturer, is not guaranteed or endorsed by the publisher.

Copyright (c) 2022 Jalali, Bell, Gorfine, Conron and Giri. This is an open-access article distributed under the terms of the Creative Commons Attribution License (CC BY). The use, distribution or reproduction in other forums is permitted, provided the original author(s) and the copyright owner(s) are credited and that the original publication in this journal is cited, in accordance with accepted academic practice. No use, distribution or reproduction is permitted which does not comply with these terms. 